\title{
Key geotechnical knowledge and practical mine planning guidelines in deep, high-stress, hard rock conditions for block and panel cave mining
}

D Cuello Newcrest Mining Limited, Australia

G Newcombe Newcrest Mining Limited, Australia

\begin{abstract}
Cadia Valley Operations (Cadia) embarked on a path of cave mining in the early 2000s with the establishment of the Ridgeway sublevel cave. The success of that mine led to a significant expansion into block caving operations, first at Ridgeway Deeps, and then to the now established Cadia East operations.

What makes Cadia unique is the high-stress, hard rock mining conditions combined with the ability to maximise investor returns through the use of very high lift heights at depths of between 1,200 to 1,400 m. Over the last decade, a significant amount of geotechnical and mining operations knowledge has been gained. A strong safety culture, combined with innovative thinking, has allowed Cadia to challenge existing industry paradigms using empirical data, a proof of concept type approach, followed by rapid implementation.

Cadia East is now poised to begin another phase of development as it continues on a multi-decade mine life to exploit over one billion safe tonnes of ore. A critical path for ensuring success is the conversion of the geotechnical knowledge into practical planning guidelines that can be easily understood and adopted during cave feasibility, establishment, and full production phases.
\end{abstract}

This paper summarises the key elements of geotechnical knowledge and its input into the mine planning for the future of Cadia Valley Operations.

Keywords: caving, hard rock, fragmentation, ramp-up, planning

\section{Introduction}

Cadia Valley Operations is one of Australia's largest gold mining operations, and is owned and operated by Newcrest Mining Limited. Cadia is located approximately $250 \mathrm{~km}$ west of Sydney, and $25 \mathrm{~km}$ south of Orange, New South Wales, Australia, as shown in Figure 1. At the time of writing, over $10 \mathrm{Moz}$ of gold has been produced from Cadia since commercial production first commenced in 1999 from the Cadia Hill open pit, then from the Ridgeway sublevel cave and Ridgeway Deeps block cave (RWD-BC), and now the Cadia East (CE) Panel Cave.
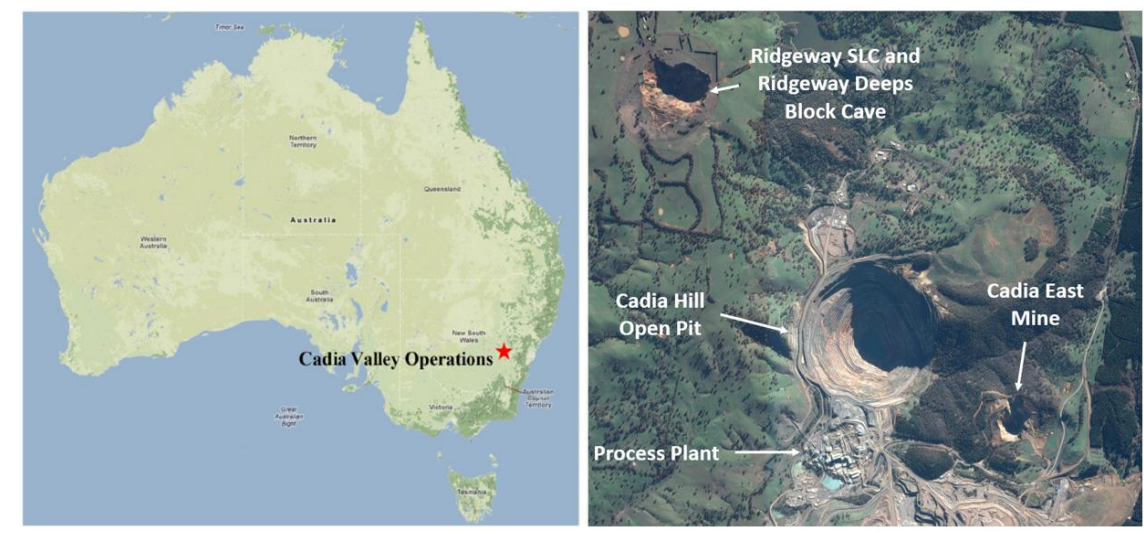

Figure 1 Location of Cadia Valley Operations and operating mines 
Starting in 2000, Newcrest has successfully developed four virgin caving operations at Cadia with a sublevel caves (SLC), one block cave (BC) and two panel caves (PC). These have all been achieved in hard rock masses, and with the evolution to panel caving, the ability to do so in deep and high-stress environments. This capability has led to the achievement of propagating two cave columns in Cadia East to surface from depths of up to $1,400 \mathrm{~m}$ a single lift. Figure 2 shows this step change in industry practice by comparing Cadia to other, established block and panel caving operations. In Figure 2, the vertical axis defined as block height is referred to the minimum distance to the cave breakthrough.

Newcrest plans to establish further panel caves, as extensions to the current PC1 and PC2 operations, over the coming decades with a 50 year future at Cadia Valley for the Cadia East deposit. These extensions will begin with a 100,000 $\mathrm{m}^{2}$ extension of PC2 to the east, and a 150,000 $\mathrm{m}^{2}$ extension to the west of PC1.

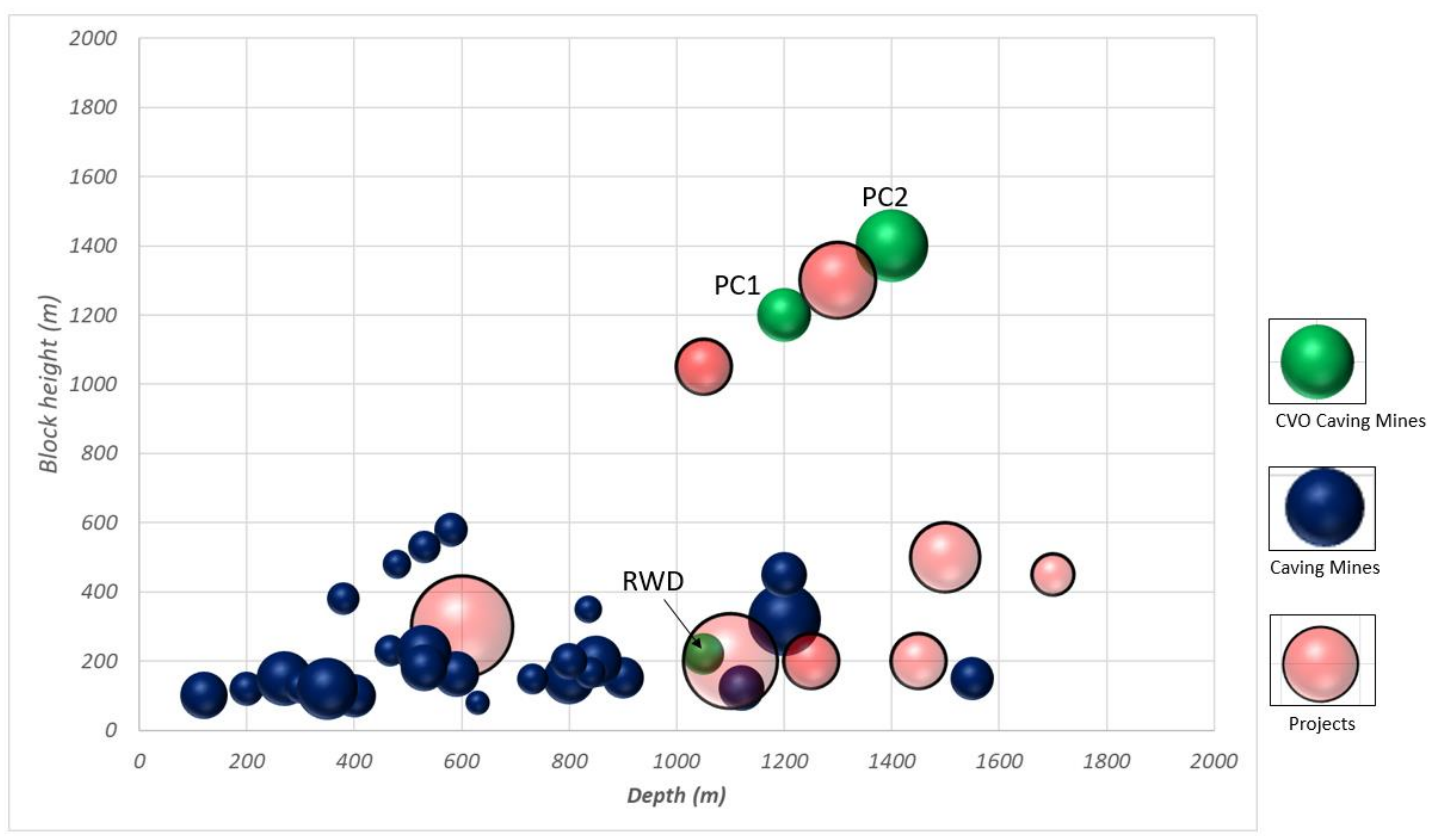

Figure 2 Caving mines' relationship between depth, block height and maximum footprint production (bubble size)

\section{Cadia geotechnical environment}

The host lithology of the RWD-BC comprises flat to low-dipping volcaniclastics and sediments of Ordovician age. Within the host sequence, there are porphyritic monzonite intrusive with mineralised ore zones concentrated on their peripheries. The mineralisation at RWD includes copper-gold sheeted quartz veins. The RWD orebody spatially consists of sediments to the south and volcaniclastic lithologies to the north, with the central areas consisting of intrusive monzonite. RWD exhibits several mine-scale faults which are typically weak and heavily altered fracture zones.

By contrast, the Cadia East lithology consists of Forest Reefs Volcanics, with a large monzonite porphyry intrusion. There are several mine-scale faults associated with this intrusion. These faults include a number of sub-vertical east-west trending faults and thrust faults. At Cadia East, four main structure types have been recognised: pyrite/phyllic/Zn-Pb faults, carbonate faults, calcite-laumontite fracture zones and chlorite faults. 
Table 1 provides a summary of the engineering parameters present at both RWD and CE.

Table 1 Changes in mine design parameters between Ridgeway and Cadia East

\begin{tabular}{|c|c|c|c|c|}
\hline & \multicolumn{2}{|c|}{ Ridgeway Deeps } & \multirow{2}{*}{$\begin{array}{l}\text { Cadia East PC1 } \\
\text { Volcanics }\end{array}$} & \multirow{2}{*}{$\begin{array}{l}\text { Cadia East PC2 } \\
\text { Volcanics }\end{array}$} \\
\hline & Volcanics & Sediments & & \\
\hline $\begin{array}{l}\text { Mean fracture frequency per metre } \\
\text { (FFM) }\end{array}$ & 3.4 & 4.4 & 3 & 3 \\
\hline $\begin{array}{l}\text { Mean unconfined compressive } \\
\text { strength (MPa) }\end{array}$ & 123 & 99 & 132 & 140 \\
\hline Mean Young's modulus (GPa) & 68 & 68 & 65 & 67 \\
\hline \multirow{2}{*}{$\begin{array}{l}\text { Mean in situ stress magnitude } \\
\left(\sigma_{1}^{\prime}: \sigma_{2}^{\prime}: \sigma_{3}^{\prime}\right)(\mathrm{MPa}) \text { and depth }(\mathrm{m})\end{array}$} & $66: 48: 35$ & & $63: 42: 36$ & $72: 48: 41$ \\
\hline & @ 1,100 & & @ 1,200 & @ 1,400 \\
\hline
\end{tabular}

\section{Geotechnical considerations for mine design and planning}

In caving operations, mine design and planning needs to consider the strategic management of geohazards such as mining-induced seismicity, airblast and inrush to be central to the design and operating caving practices. Hence, the design and planning assumptions need to be based upon demonstrated caving practices or practices with significant technical substance to be able to deal with the process of establishing and operating a block cave. At Cadia, these areas for planning have been divided into:

- Fragmentation.

- Hydraulic fracturing.

- Mine design.

- Cave management.

- Stress abutment zone.

\subsection{Fragmentation}

Fragmentation of rock is a key parameter in setting the cave establishment design and production systems. The undercut design and secondary break systems chosen are reliant on the knowledge of these parameters as the methods employed to deal with fragmentation form a large part of the anticipated economic return for the cave. This is in contrast to the standard estimation process, as shown by Brunton et al. (2016), where the difficulty in accurately predicting the fineness of the ore parameters prior to mining can lead to significant divergence from prediction to reality. Understanding the initial fragmentation, the way it changes over time, and the impacts of this on production have been a significant learning for Cadia.

Empirical evidence and analysis from Cadia shows that in hard rock caves, with high ore columns, the resulting fragmentation and its effect on production performance can be divided into four categories as shown in Figure 3. They are:

- Category 1: Blasted ore from upper section of the drawbell and undercut. This can vary between 5-25 $\mathrm{m}$ of the ore column above the undercut level.

- Category 2: Primary fragmentation from the bottom part of the ore column, immediately above the undercut. This corresponds to between 5-50 m of the ore column.

- Category 3: Fragmentation corresponding to blocks formed during cave propagation, inside the loosening zone, where the start of secondary comminution starts to become apparent. This is mainly material from the first $50-90 \mathrm{~m}$ of the ore column. 
- Category 4: Fragmentation resulting from attrition and abrasion of blocks within the flow stream with a significant reduction in large, hang-up forming, rocks. A further category (4B) can also start to materialise as a result of significant attrition, or weaker rock mass, with very fine material presenting at the drawpoint.

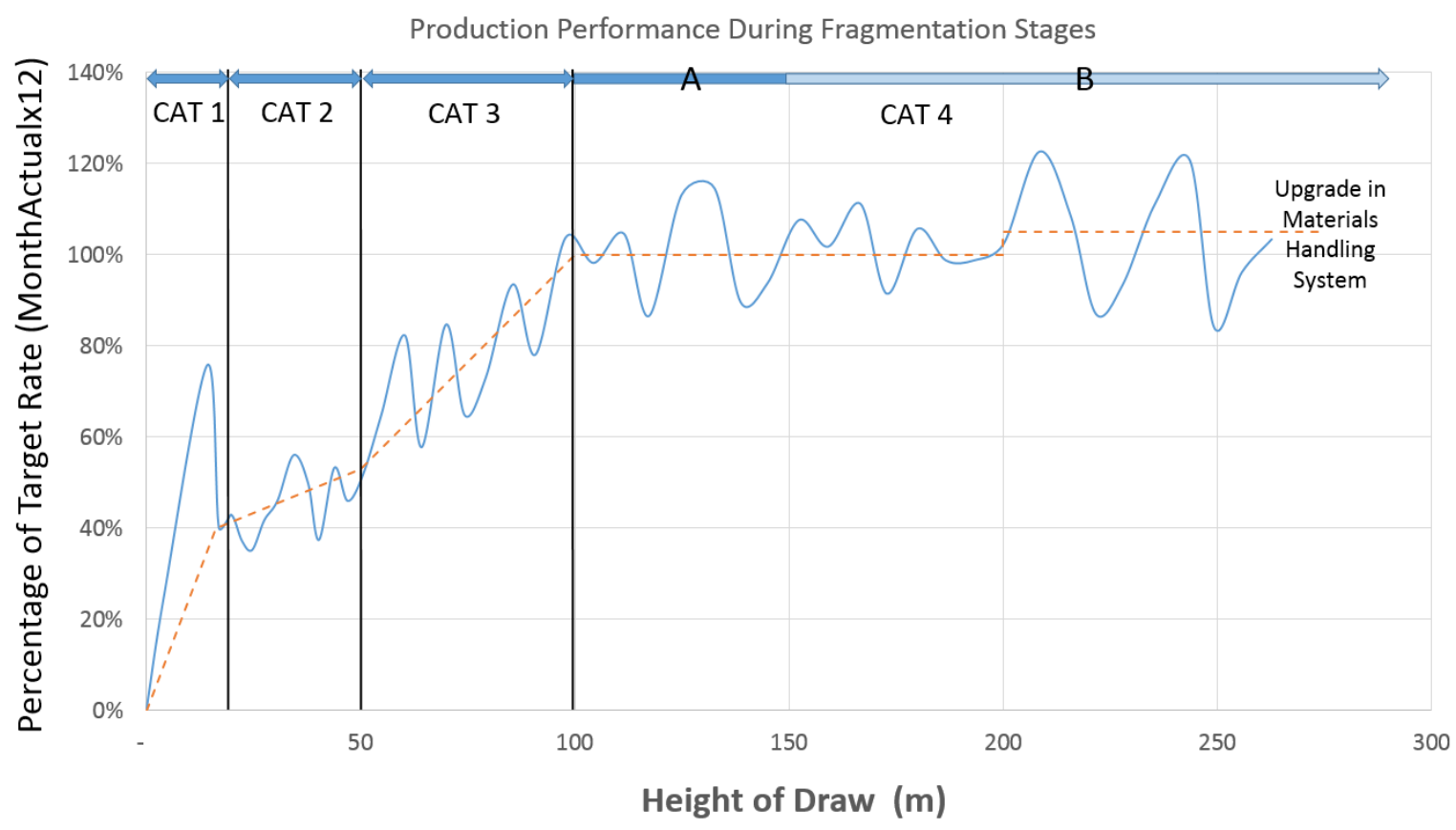

Figure 3 Fragmentation categories and the effect on mine performance at Cadia

In practice, a significant amount of the design and optimisation of a block cave project is focused on Category 1-3 ore. The reasons for this are:

- These three categories define the ramp-up period of a block cave when economic metrics such as capital cost and return on investment are most challenged.

- The high quantity of large-volume rocks requires significant investment in management time and resource allocation due to the difficulties associated with secondary breakage resources and hang-ups.

This is also aligned to the best benchmark operations, often used by companies to compare practices and anticipated outcomes, and is based off caves set 250-300 m high, meaning that these categories account for one third of all ore material, thus representing the most significant period of cave life. However, in a cave with a taller column of ore to be extracted (at Cadia East the columns are up to 1,200 $\mathrm{m}$ ) the period that is the most significant is the Category 4 period, which represents up to $90 \%$ of the life of a drawpoint. This period is defined by:

- Higher levels of finer fragmentation making loading operations more productive through higher bucket fill factors and faster loading times.

- Significant improvement in the management of the production level processes due to lower levels of intervention (secondary break events) and the ability to manage interventions in a planned systematic way.

- The ability to reduce equipment and labour levels, simplify operations and reduce the mining cost.

- The ability to raise the overall mine production rate by debottlenecking the system constraints and taking advantage of the performance opportunity that operational stability provides (Figure 3).

- The ability of the ore processing facility to increase its throughput due to the uplift gained from autogenous grinding within the cave. 


\subsubsection{Changes in mine design parameters between Ridgeway and Cadia East due to fragmentation}

Learning from each successive operation has been a key theme at Cadia. The RWD and CE-PC1 mines were mined sequentially and have similar sized footprints $\left(\approx 70,000 \mathrm{~m}^{2}\right)$ however the performance and production outcomes were very different. Key learnings were taken from the implementation of RWD, Newcrest's' first block cave mine, and transferred into the CE-PC1. The main changes are tabulated in Table 2.

Table 2 Changes in mine design parameters between Ridgeway and Cadia East

\begin{tabular}{lll}
\hline Constraint & Ridgeway & Cadia East PC1 \\
\hline Crusher type & Jaw & Jaw-Gyro \\
Maximum crusher feed size $\left(\mathrm{m}^{3)}\right.$ & 1 & 3 \\
Material handling system (MHS) & Two crushers to achieve & One crusher to achieve \\
capacity (Mtpa) & 10 & 15 \\
Extraction level layout & Herringbone & El Teniente \\
Loader size (t) & $14-17$ & 20 \\
Undercut style & Advanced crinkle cut & Post undercut \\
Undercut height (m) & 5 & 20 \\
Blasted material (t/m ${ }^{2)}$ & 16 & 47 \\
Hydrofracturing breadth & $1 / 3$ of footprint & Entire footprint \\
Hydrofracturing height (m) & 80 & 400 \\
Annual production rate (Mtpa) & 10 & 15 \\
\hline
\end{tabular}

The most significant of the changes in effect can be considered as:

- Change to a crusher with a larger top size volume: Significantly reducing secondary break events, complexity, operating costs and the ramp-up time.

- Change to a larger loader class: Increasing the output in each working drive by $10-20 \%$ and allowing larger volume rocks to be moved directly to the crusher.

- Change to El Teniente layout: Allowing the loaders to load square to the orientation of the drawbell and reducing the number of hang-ups which the loader cannot address.

- Preconditioning and undercut shape: Reducing the number of oversize rocks and hang-ups, minimising the time spent dealing with complex secondary break issues. As seen in Figure 4 , an improvement of up to 10 times can be seen in hang-up frequencies when comparing similar rock masses and stress levels. 


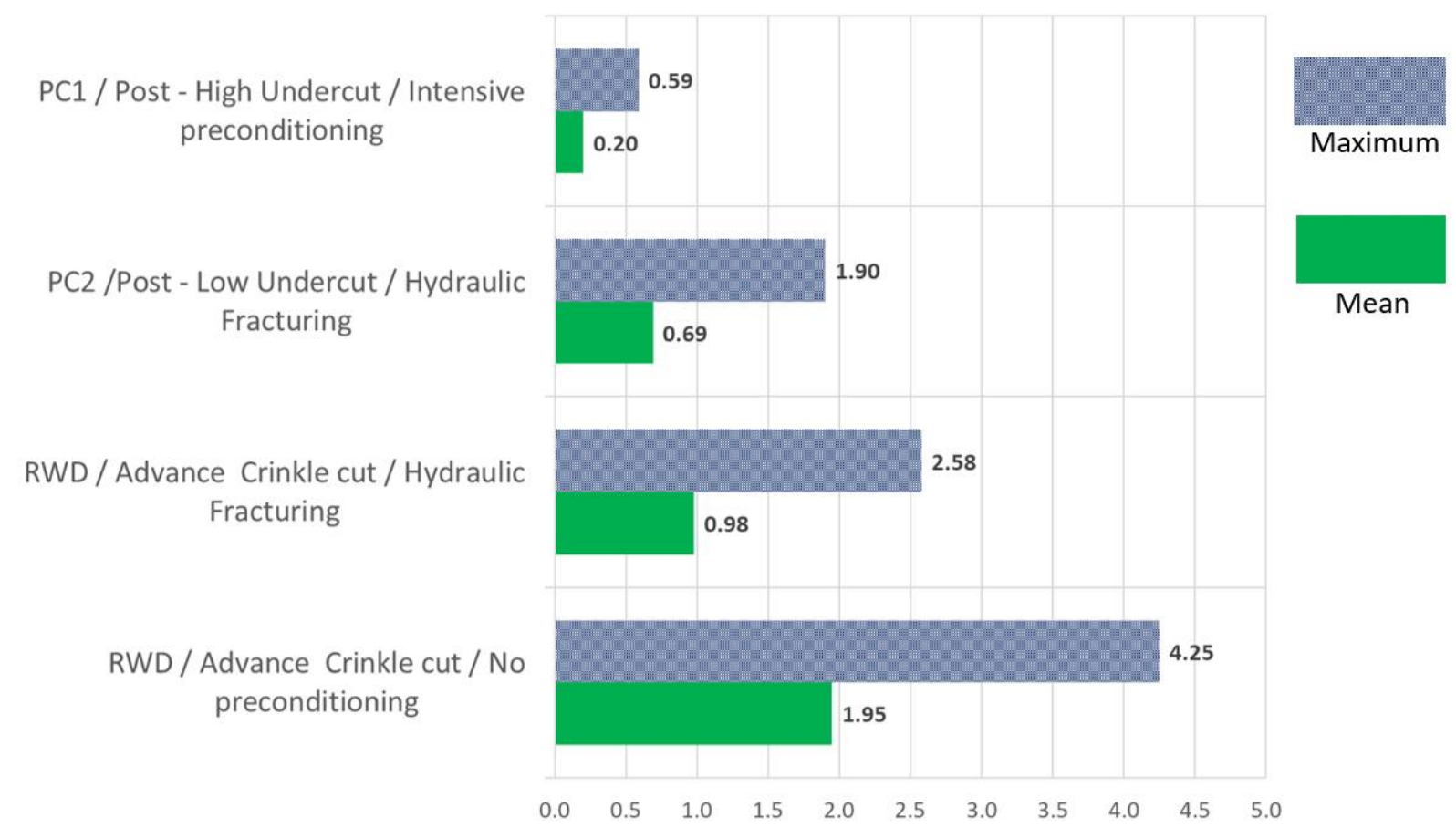

Figure 4 Comparison of hang-up frequency per 1,000 t between RWD and Cadia East for Category 2

The benefits of understanding the fragmentation of the orebody has resulted in some key learnings:

- The chosen caving layout, undercut design and equipment will control the amount of material in Categories 1 and 2. The learnings from RWD and Cadia East provide comparison for different cave establishment strategies and fragmentation performance.

- In large columns, Category 4 fragmentation accounts for up to $90 \%$ of the drawpoint life. Planning for this eventuality will assist the operation to take advantage of the production benefits offered by finer fragmentation and improve the safety of personnel by implementing strategies to reduce the impact of the changing work environment.

\subsection{Hydraulic fracturing}

Hydraulic fracturing, in order to precondition the rock mass, is aimed at degrading the quality of a competent rock mass to assist in obtaining an improved cave performance and has become an integral part of cave mining at Cadia.

The first industrial application of hydraulic fracturing (HF) in Cadia occurred at RWD from August 2008 to February 2009 for an $80 \mathrm{~m}$ column within part of the orebody. Cadia East conducted hydrofracturing programs for PC1 and PC2. These programs were completed from 2011-2013 and from 2014-2016, respectively, and aimed to precondition the $400-550 \mathrm{~m}$ of the base of the ore column. Cadia has now completed over 5,000 downhole fractures and a summary of key fracturing parameters for each mine is shown in Table 3. 
Table 3 Summary of key features of hydraulic fracture campaign

\begin{tabular}{llll}
\hline Mine & RWD & PC1 & PC2 \\
\hline Number of fractures & 508 & 1,619 & 2,640 \\
Fracture spacing $(m)$ & 3 & 2.5 & 2 \\
Long axis from injection point $(m)$ & 50 & 60 & 60 \\
Short axis from injection point $(m)$ & 35 & 25 & 30 \\
Average hole depth & 250 & 350 & 520 \\
Fractures per shift (min. and max.) & $2-9$ & $6-13$ & $6-13$ \\
Break down pressures Mpa (average and max.) & $49-70$ & $48-71$ & $48-76$ \\
\hline
\end{tabular}

\subsubsection{Hydraulic fracture design}

The hydraulic fracture program requires the definition of:

- Hydraulic fracturing operational parameters.

- Cave engineering level.

- Calculation of injection system requirement.

- Equipment.

\subsubsection{Hydraulic fracturing operational parameters}

The operational parameters for the hydraulic fracture program are critical to design the intensity of preconditioning achieved. These are summarised in Table 4.

Table 4 Example of recommended hydraulic fracturing operational parameters

\begin{tabular}{ll}
\hline Operational parameter & Value \\
\hline $\begin{array}{l}\text { Vertical fracture spacing } \\
\text { Designed fracture } \\
\text { geometry }\end{array}$ & $\begin{array}{l}\text { Fractures are assumed to be sub-horizontal circles, using a fracture short } \\
\text { axis diameter based on rock mass conditions ( } 60 \mathrm{~m} \text { at Cadia). The fracture } \\
\text { plane is perpendicular to } \sigma_{3}\end{array}$ \\
Fracture hole spacings & $\begin{array}{l}\text { Offset grid } 52 \times 60 \mathrm{~m} . \text { Drillholes and access drives are aligned to the } \\
\text { extraction drive orientation to assist in the management of fracturing } \\
\text { activities and cave establishment activities }\end{array}$ \\
$\begin{array}{l}\text { Fracture hole } \\
\text { orientations }\end{array}$ & $\begin{array}{l}\text { Vertical orientation } \pm 20^{\circ} . \text { This enhances hole stability, aligns subparallel } \\
\text { development solutions associated with the cave engineering level }\end{array}$ \\
\hline
\end{tabular}

\subsubsection{Cave engineering level design}

The cave engineering level development is to be utilised for both hydrofracturing and geotechnical instrumentation installation including open holes, geophones, network smart markers and cave trackers. The design considerations for the cave engineering level include:

- The chosen vertical distance from the undercut level is governed by the ore column required to be treated. 
- Lateral development is designed based on fracture spacings and orientations to ensure interaction between fractures within the treated rock mass.

- The need for dynamic ground support to be installed, required as the cave approaches the level.

- Avoiding or minimising the future interaction of lateral development with the cave due to the risk of airblast as the cave passes through the level. An engineered plug may be required to separate the cave interaction zone from drives where personnel require access.

The evolution of the cave engineering levels at Cadia are shown in Figure 5. The changes can be described as:

- Single drive: Successful hydrofracturing with limited coverage due to angle limitations and interaction at collars.

- Multi-drive grid: Significantly increased footprint coverage using vertical holes.

- Optimised grid: Same footprint coverage utilising significantly lower development and reducing cost through the use of angled holes. Installation of a ring drive $150 \mathrm{~m}$ from the future cave position to ensure adequate monitoring positions for full cave life monitoring.

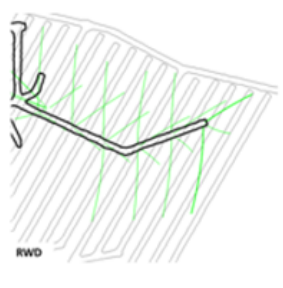

A

Single Drive

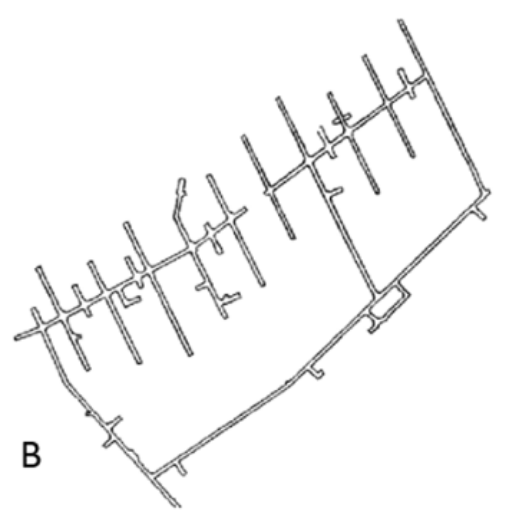

Multi Drive Grid

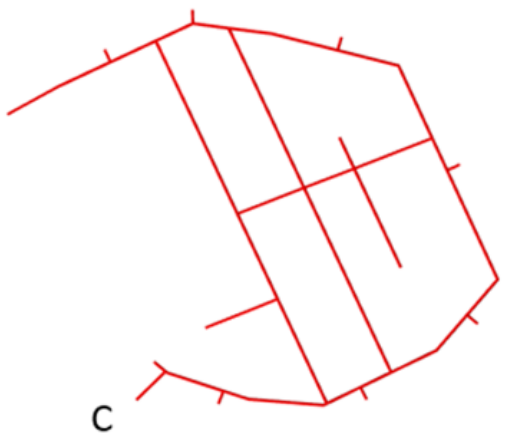

Optimised Grid \& Ring Drive

Figure 5 Cave engineering horizon evolution

\subsubsection{Calculation of injection system requirements}

There are two key factors in the calculation of the injection system requirements:

- Fracture initiation: Fracture initiation or breakdown pressure is the pressure required to initiate a fracture and is usually the highest pressure reached during a fracture treatment. For virgin ground at Cadia and at a depth below $800 \mathrm{~m}$, the maximum breakdown pressure can be determined using Equation 1 . This equation is based on empirical evidence with a $99 \%$ confidence level.

$$
\text { Max Pc }=0.0447 \times \text { depth }+23.4
$$

- Fracture propagation: The recommended fracture run time and flow to achieve the designed fracture geometry at Cadia is $30 \mathrm{~min}$ at $425 \mathrm{~L} / \mathrm{min}$.

\subsubsection{Equipment}

A general equipment list for a hydraulic fracturing system is detailed below. Size and specifications for each piece of equipment are dependent upon individual site requirements.

- Injection pump.

- Injection lines.

- Packer inflation system. 
- Flow control and monitoring system.

- Drill rig or machine to position and hold injection line and straddle packers.

- Straddle system - downhole injection isolation system.

- Power and water tanks.

\subsubsection{Hydraulic fracturing key learnings}

Cave performance from RWD, PC1 and PC2 have confirmed the substantial improvement from hydraulic fracturing regarding three key areas:

- Cave propagation: Increase the caveability of the orebody through the introduction of new sub-horizontal fractures. This has a direct, positive effect on eliminating/mitigating airblast risk and improved draw rates.

- Primary fragmentation: Reducing the number of oversize rocks reporting to the drawpoints, which has a positive impact on production ramp-up. To maximise the benefit, this requires fractures to be created as close to the elevation of the undercut level as possible.

- Reduction in seismic hazard: Reduction in magnitude of large seismic events within the treated volume during undercutting and cave propagation. Similar findings were found at the El Teniente mine (Pardo \& Rojas 2016).

\section{$4 \quad$ Mine design}

\subsection{Extraction level}

Experience gained from Cadia has led to the decision to adopt the standard El Teniente layout with a spacing of $32 \times 20 \mathrm{~m}$, a $60^{\circ}$ turn out angle and $5.3 \mathrm{~m}$ wide $\times 4.6 \mathrm{~m}$ high drive as the preferred layout for future caving extensions. The El Teniente layout has been selected for the following reasons:

- It has greater structural integrity than other layouts because the minor apex is shorter and more stable.

- Increasing the distance between the extraction drive delays the rill material from the drawpoint interacting with extraction drive due to drawpoint brow damage.

- Smaller spans at intersections with lower probability of damage from dead loads above the extraction level.

- Less damage to the pillars and development efficiency during development due to long, straight excavations, as opposed to a herringbone layout.

- A better distribution of drawpoints for even drawdown of the muck pile.

One disadvantage of this layout is the sharper turning angle of $60^{\circ}$ compared to the herringbone layout angle of $45^{\circ}$, slowing the load-haul-dump (LHD) operation.

\subsection{Cave establishment method and drawbell design}

The selection of the preferred cave establishment method is complex as there is a significant number of trade off and linked decisions to be made which significantly impact the process to establish the cave and the final outcome of the process. These decisions are based on:

- The safety of personnel.

- Geotechnical and operational reliability of the extraction level.

- Business returns. 
- Flexibility to mitigate issues encountered in construction, i.e. changes in rock mass, mine-induced seismicity, structures and execution delays.

Clearly, setting the goals of the cave establishment method is paramount at the beginning of the project. The functional intent of Cadia's designs are summarised below:

- Provide stable protection for the extraction drives over the cave life. Resilience to manage mine-induced seismicity during cave establishment and to maintain extraction level serviceability during the mature stage of the cave.

- Initiate and guarantee caving across the entire footprint.

- Shape the major apex to promote and maximise the flow of ore into the drawbells.

Cadia has used a number of establishment methods in its caving operations. The key associated parameters are shown in Table 5. Also, in Figure 6, average monthly undercutting rates implemented by Newcrest are compared with industry norms.

Table 5 Cave establishment parameters at Cadia

\begin{tabular}{lllll}
\hline Mine & $\begin{array}{l}\text { Undercut } \\
\text { variant }\end{array}$ & Undercut style & $\begin{array}{l}\text { Pillar dimensions } \\
(\mathbf{L} \times \mathbf{W} \times \text { major } \\
\text { apex height })\end{array}$ & $\begin{array}{l}\text { Total } \\
\text { undercut } \\
\text { area }\left(\mathbf{m}^{2}\right)\end{array}$ \\
\hline RWD & Advance & Crinkle cut & $30 \times 18 \times 20$ & 70,000 \\
PC1 & Post & High lift at $20 \mathrm{~m}$ & $32 \times 20 \times 26$ & 73,000 \\
PC2 West & Post & Low lift & $32 \times 20 \times 26$ & 50,000 \\
PC2 East & Advance & Flat & $32 \times 20 \times 26$ & 60,000 \\
\hline
\end{tabular}

300000

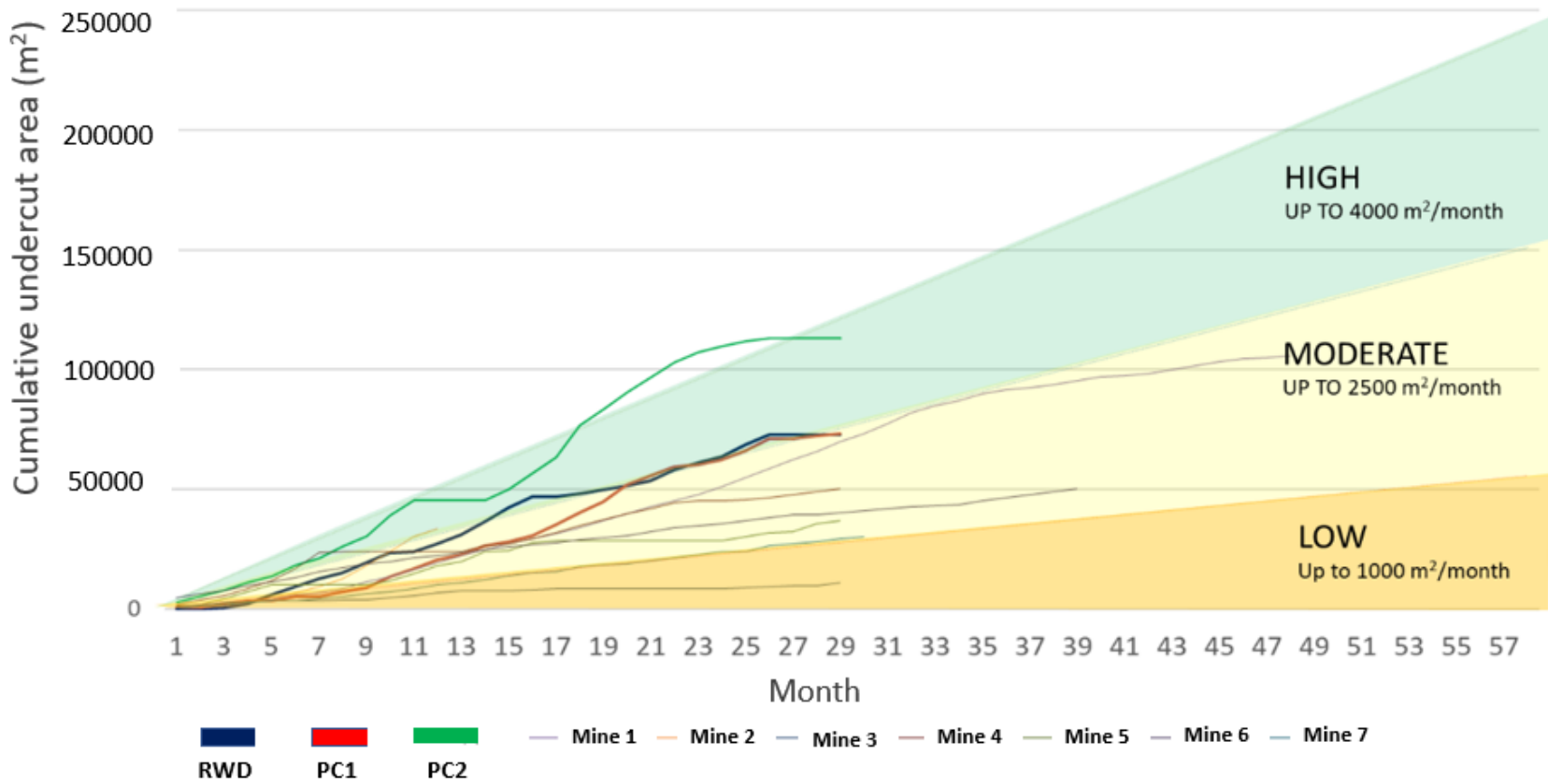

Figure 6 Average monthly undercutting rate from first undercut firing 
Key learnings:

- Best practice in drill and blast, as well as rigorous QA/QC, are of paramount importance in the success of any cave establishment method.

- Mine-induced seismicity is an inherent part of cave establishment and cave growth. Dynamic ground support is required in all excavations (drives and infrastructure) that are not shadowed by the undercut.

- Early production ramp-up is highly influenced by the selection of the undercut variant and style selection. A comparison can be seen in graphs shown in Figure 7. As seen in Figure 7, post-undercut delivers a substantially faster ramp-up when compared with advance undercut.
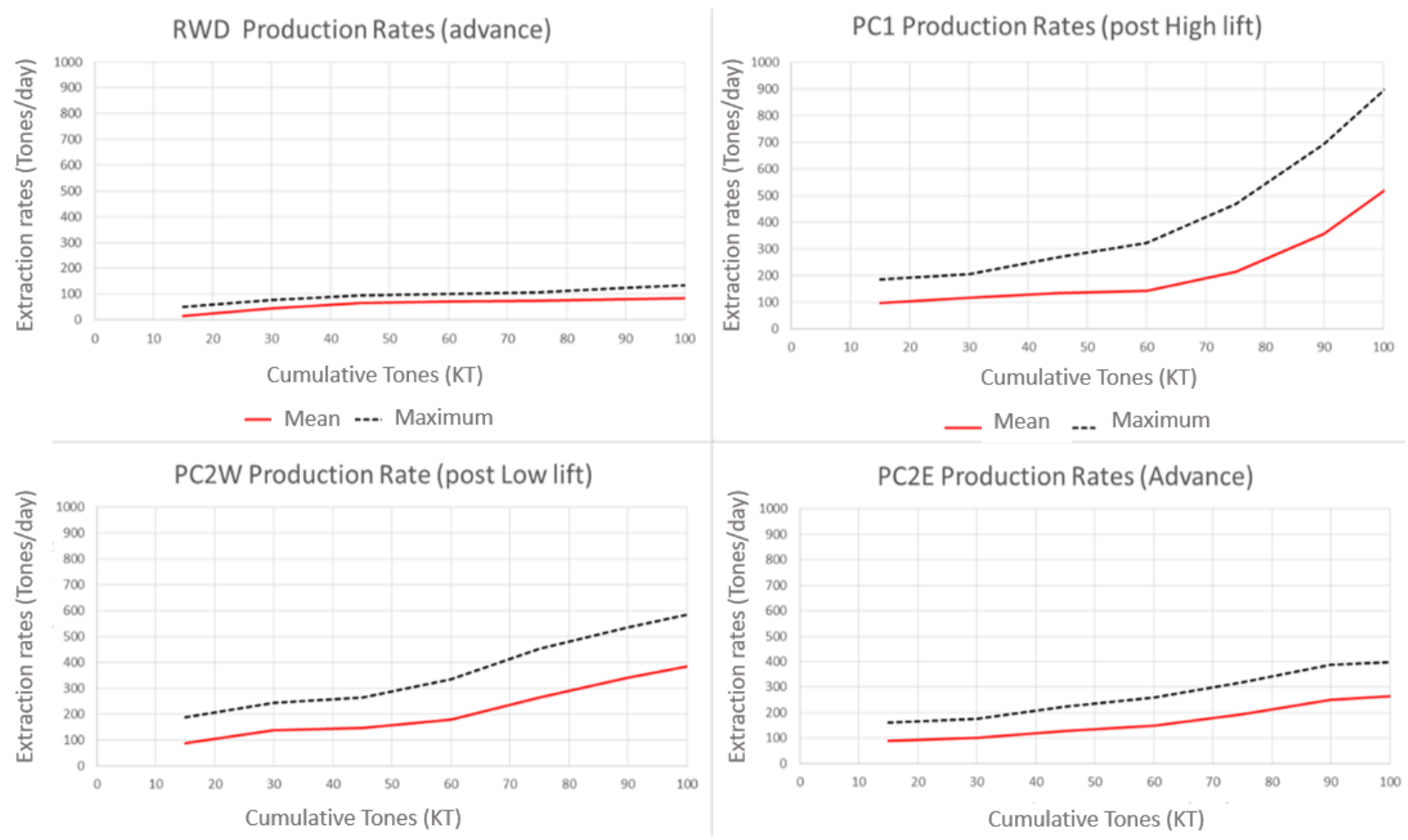

Figure 7 Historic production rates in caving mines at Cadia Valley

\section{Cave management}

The long-term functional intent of the cave management processes is to draw the stated long-term ore reserves into the drawbells for transport to the surface for processing. From initiation of the cave through to production from a mature cave (Figure 8), the draw strategy targets four goals:

1. Initially, to manage the hazard of airblast from the cave whilst optimising production. Draw of material from the cave in excess of the caving rate could lead to an unacceptable airgap developing.

2. To then manage the stress in the cave abutments and the seismic response of the rock mass.

3. To ensure that the cave propagates as planned and is altered where the formation of irregular cave profiles (or chimney caving) occur. This is inclusive of managing areas of unfavourable geological structures or rock mass changes.

4. Finally, drawing in such a way from within the caved zone to manage dilution entry and maximise ore recovery.

In order to achieve these goals and establish the final cave draw sequence, the planning of the cave needs to consider the rock mass within the mine and then apply the caving rate constraint (maximum draw rates), the cave establishment constraint (drawbell opening rate and sequence), and the production system constraint 
(ramp-up rate and total system capacity) to generate an overall production plan. In order to communicate these goals, we have broken the sequence into management zones (Figure 8) to ensure each area achieves its part in the overall goal.

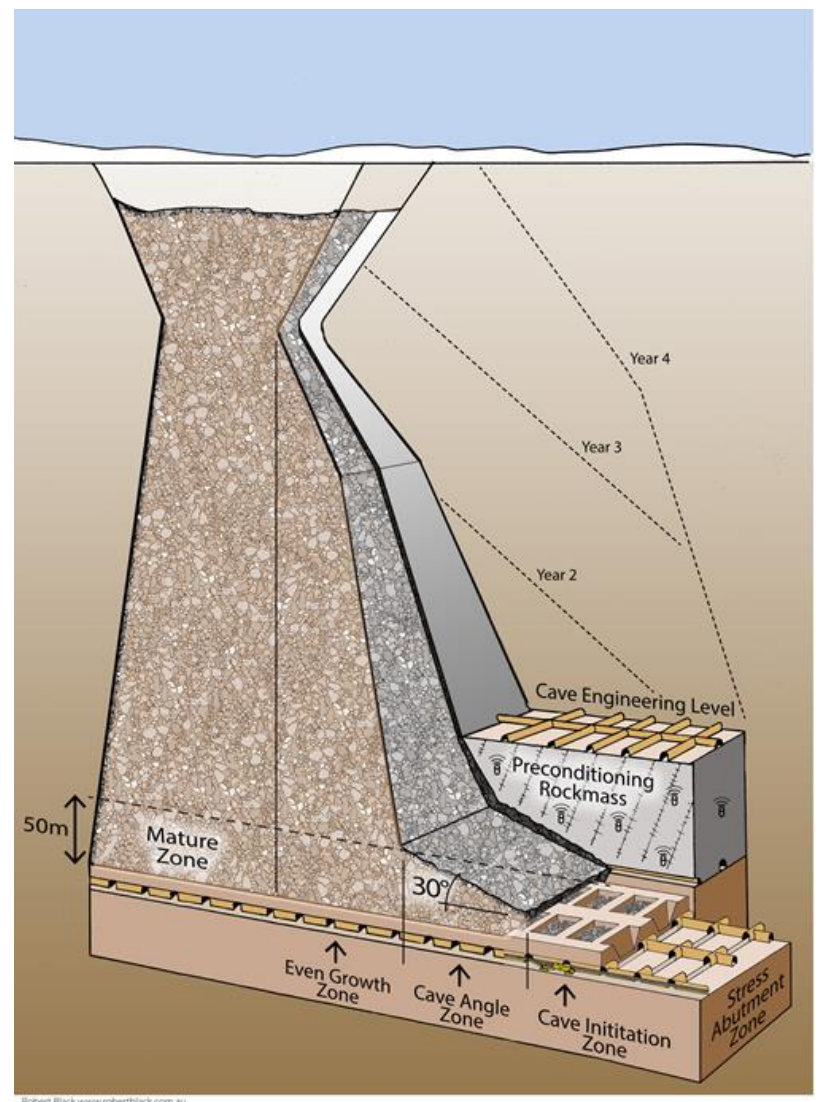

\section{Figure 8 Cave evolution zones}

\subsection{Cave initiation zone}

Cave initiation is the transition from a stable to an unstable cave back leading to caving. In this stage, the progression of the cave back may be slow or intermittent with the possibility of excessive airgaps being developed. Cave initiation is applicable to virgin caves as well as to cave extensions. Cave initiation has two very important parameters, and they are:

1. Cave initiation point: This corresponds to the location where the undercut process will commence and the direction to which the undercut front will retreat. The cave initiation point has to be defined for virgin caves and cave extensions as it provides the starting point for an increase in mine-induced seismicity. A thorough geotechnical analysis is required before selecting the cave initiation point.

2. Critical dimension: This refers to the critical hydraulic radius required to initiate the cave. Review of historic performance from RWD, PC1 and PC2 has shown that once the rock mass has been preconditioned, the minimum hydraulic radius to initiate the cave varies between 33 and $36 \mathrm{~m}$, equivalent to 21 and 26 active drawbells, respectively. In the early stages of cave initiation, the recorded cave rates varied between 500 and $1,000 \mathrm{~mm} /$ day. During cave propagation, cave rates have varied between 3,000 and $4,700 \mathrm{~mm} /$ day within preconditioned volumes. 


\subsection{Draw angle zone}

Cadia East has adopted the use of the draw angle, also known as the extraction angle (Landeros et al. 2012), to manage the critical transition phase of the cave between initiation point, the broader cave growth, and mature cave phases. This concept is used as a geotechnical/planning tool to achieve the best cave outcome possible by optimising the competing demands of cave establishment - production and undercutting.

The draw angle concept does this by defining this zone as the angle formed between the last fired drawbell and the height of draw inside the drawbell adjacent to steady-state flow. This angle is required to be maintained between 30 and $45^{\circ}$, and cave growth is strictly controlled through draw (see yellow zone in Figure 9). Use of the cave angle tool helps to ensure:

- Management of the seismically active volume above the footprint to minimise the potential for large, damaging seismic events.

- That an excessive airgap is not being developed to reduce airblast potential.

- Prevents the rilling of material from one sector into another which would impede cave growth.

In extension caves, the cave is started adjacent to an existing cave and there is the potential for an uncaved pillar to be formed between the existing cave and the new cave. The application of the extraction angle in conjunction with rock mass preconditioning and cave initiation are important controls to reduce the likelihood of this occurring.

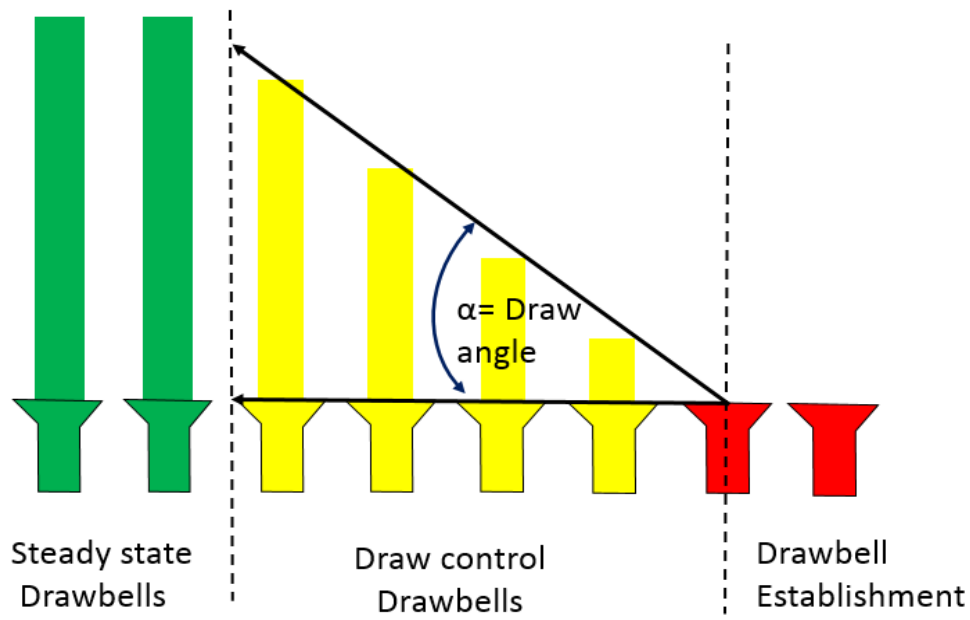

Figure 9 Draw angle concept

\subsection{Even growth and mature cave zones}

The even growth zone is applied in a region where cave initiation has commenced and production is established. Due to the very tall columns at Cadia, this zone is a more significant feature of the cave plan than in other operations, and its application is initiated once Category 3 ore becomes apparent in the mine and secondary break interventions start to decline (50 m of draw). In order to achieve the best outcome, all drawpoints within this zone are to be bogged as evenly as possible whilst balancing this with practically achieving the best economic outcomes.

The functional intent of 'even draw' at Cadia is to ensure best practice draw strategies are used to promote the best cave zone possible. To achieve this, we use even draw across the zone to maximise cave growth with KPIs for quality of draw which are defined as:

- A drawpoint is considered compliant if it falls within $\pm 15 \%$ of the plan.

- A month is compliant if $80 \%$ of drawpoints are compliant.

- A quarter is compliant if $90 \%$ of drawpoints are compliant. 
The mature cave zone is defined as the zone where the cave has ceased growing and draw is focused on safe, low-cost operations, maximising productivity and maximising ore reserves through good draw practices. Draw in this zone uses the same compliance metrics. However, the draw plan is weighted towards safe production goals as the business requires.

\subsection{Cave draw rates}

Overall draw control rules are limited and dictated by the rock mass response. These are based on the lower recorded cave back propagation rates and the bulking factor of the cave is used to calculate the maximum allowable draw rates. Due to the very high columns at Cadia East, these draw rates vary over time (as the height of draw changes). Typical draw rates are shown in Table 6, and estimated bulking factors in Table 7 , respectively.

Table 6 Recommended maximum extraction rates applicable during cave propagation for preconditioned volume (Note: $\mathrm{dp}=$ drawpoint)

\begin{tabular}{lllll}
\hline $\begin{array}{l}\text { Height of cave } \\
\text { back }(\mathbf{m})\end{array}$ & $\begin{array}{l}\text { Draw rate } \\
\mathrm{t} / \mathrm{dp} / \mathrm{day}\end{array}$ & $\mathrm{t} / \mathrm{dp} / \mathrm{day} / \mathbf{m}^{2}$ & $\mathrm{t} / \mathrm{dp} / \mathrm{month}$ & $\mathrm{mm} / \mathrm{day} / \mathrm{dp}$ \\
\hline $0-100$ & 100 & 0.30 & 3,000 & 111 \\
$100-200$ & 150 & 0.47 & 4,500 & 167 \\
$200-300$ & 200 & 0.63 & 6,000 & 223 \\
$>300$ & 320 & 1.00 & 9,600 & 357 \\
\hline
\end{tabular}

Table 7 Estimated bulking factors for Cadia East before breakthrough

\begin{tabular}{lll}
\hline $\begin{array}{l}\text { Height of cave } \\
\text { back }(\boldsymbol{m})\end{array}$ & $\begin{array}{l}\text { Bulking factor (low } \\
\text { cave back regions) (\%) }\end{array}$ & $\begin{array}{l}\text { Bulking factor (high } \\
\text { cave back regions) (\%) }\end{array}$ \\
\hline$<120$ & 41 & 20 \\
200 & 29 & 19 \\
300 & 27 & 17 \\
400 & 24 & 14 \\
500 & 18 & 11 \\
600 & 18 & 11 \\
800 & 16 & 9 \\
\hline
\end{tabular}

\subsection{Stress abutment zone}

The stress abutment zone includes all excavations which lie within a 70 to $85 \mathrm{~m}$ zone ahead of the undercut front and $15 \mathrm{~m}$ inside the undercut front (Figure 10). The strategic placement of critical infrastructure, such as crusher chambers, needs to consider an extension of the 70 to $85 \mathrm{~m}$ delineation as a larger standoff distance is required. In Cadia East, the standoff distance for critical infrastructure is 110 to $130 \mathrm{~m}$, depending on elevation. Dynamic support installation has also been identified as a requirement to ensure the survivability of the excavation in the event of a large seismic event. Abutment stress zones are defined based on the following criteria:

- Areas where $\sigma_{1} /$ UCS $>0.6$ (ratio between maximum principal stress and unconfined uniaxial strength for the intact rock). 
- Stresses are likely to increase due to undercutting or cave growth.

- Areas that have higher propensity to experience rockburst.

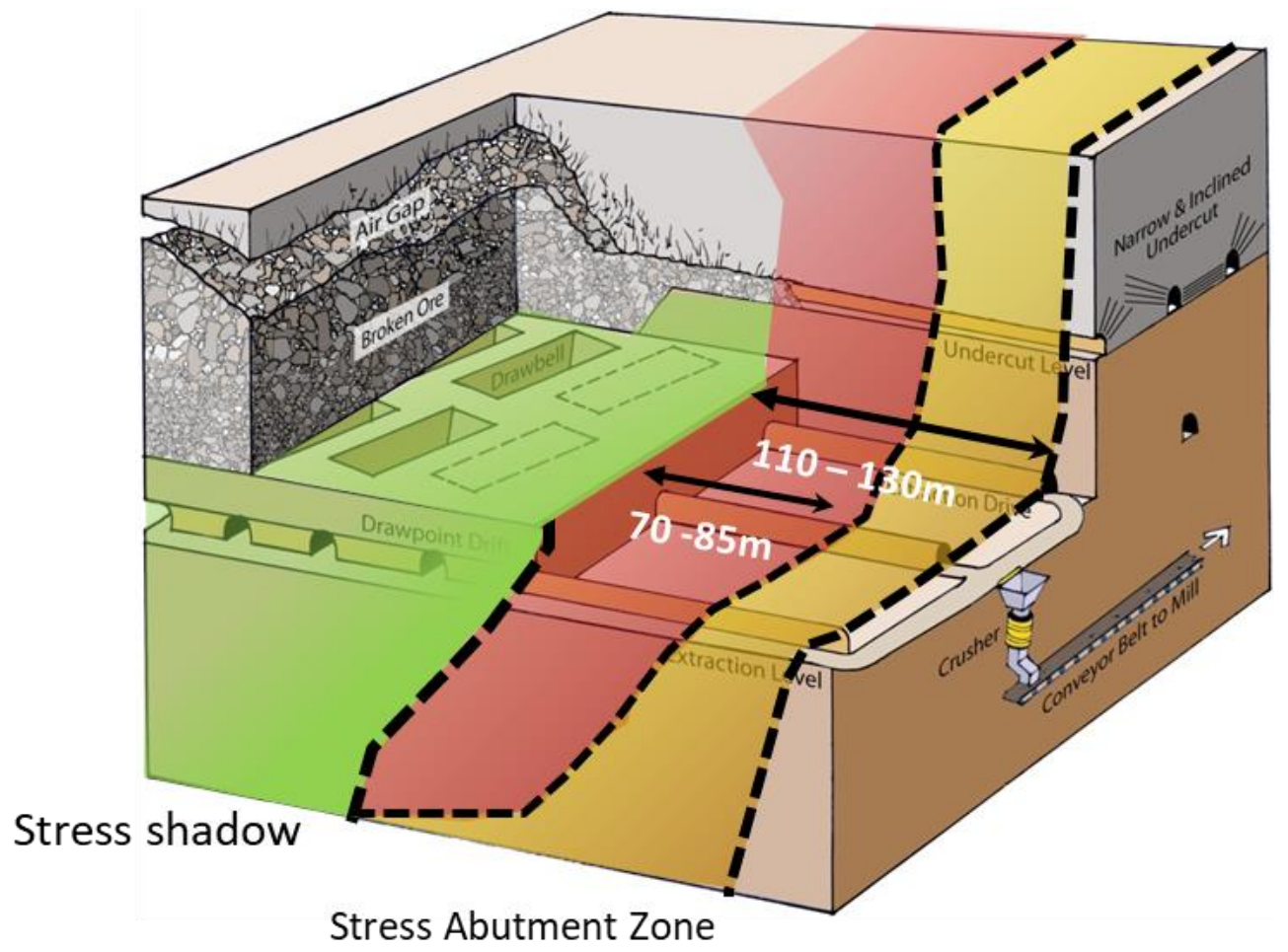

Figure 10 Stress zones within a cave footprint (after Flores 2014)

\section{$6 \quad$ Newcrest's design and operational caving rules for block and panel caving}

The caving rules are the result of the learnings from more than a decade of caving experience and are aimed to collect and summarise critical design and operational principles to ensure a safe and profitable caving mine. Based on Newcrest's experience, the caving process has been defined as the following four stages:

1. Cave establishment.

2. Cave initiation.

3. Cave propagation.

4. Cave breakthrough.

\subsection{Cave establishment rules}

The cave establishment rules shown in Table 8 apply to activities related to the operational readiness set-up of the extraction level and material handling system. These activities include, but are not limited to, the following:

- Rock mass preconditioning.

- Mine development.

- Drawbell commissioning.

- Civil work.

- Critical infrastructure construction. 


\section{Table 8 Cave establishment rules}

\begin{tabular}{|c|c|c|}
\hline Cave establishment rules & Design/operation & Risk to mitigate \\
\hline $\begin{array}{l}\text { Geological structures, stress orientation and lithological contacts } \\
\text { shall be captured and considered proactively before establishing the } \\
\text { undercut and extraction drives, and cave front orientations }\end{array}$ & Design & $\begin{array}{l}\text { Rockburst and } \\
\text { collapses }\end{array}$ \\
\hline $\begin{array}{l}\text { Geological structures shall be considered and proactively used to } \\
\text { assist caving as they drive both cave propagation and seismic } \\
\text { response }\end{array}$ & Design & $\begin{array}{l}\text { Rockburst and caving } \\
\text { stall }\end{array}$ \\
\hline $\begin{array}{l}\text { All three dimensions shall be considered to ensure the extraction } \\
\text { layout is robust, stable and able to withstand abutment stresses } \\
\text { (e.g. extraction and drawpoint drives spacing, and major apex } \\
\text { height) }\end{array}$ & Design & $\begin{array}{l}\text { Rockburst and } \\
\text { collapses }\end{array}$ \\
\hline $\begin{array}{l}\text { Preconditioning by hydrofracturing shall be used as a tool to } \\
\text { manage the induced seismicity around the entire cave zone and/or } \\
\text { on the geological structures and/or main underground } \\
\text { infrastructure (e.g. crusher chamber, crib room, workshop, vent } \\
\text { raises, main accesses, and conveyor decline) }\end{array}$ & Design & Rockburst \\
\hline $\begin{array}{l}\text { To enhance cave propagation, reserves recovery and fragmentation, } \\
\text { the use of intensive preconditioning (hydrofracturing and confined } \\
\text { blasting) shall be implemented }\end{array}$ & Design & $\begin{array}{l}\text { Caving stall, oversize } \\
\text { and reserves losses }\end{array}$ \\
\hline $\begin{array}{l}\text { To reduce the risk of strainburst during the footprint development } \\
\text { in abutment zones, destressing techniques and dynamic support, } \\
\text { including the drive face, shall be used }\end{array}$ & Operation & Strainburst \\
\hline $\begin{array}{l}\text { This shall also consider incorporating automatic drilling and charging } \\
\text { equipment to reduce exposure to personnel. Development firing } \\
\text { exclusion periods shall also be implemented for headings with high } \\
\text { strainburst risk }\end{array}$ & & \\
\hline $\begin{array}{l}\text { To reduce the risk of high-stress pillars and improve the longevity of } \\
\text { the extraction level, the majority of the extraction drives shall be } \\
\text { developed under a shadowed stress environment (behind the cave } \\
\text { front) }\end{array}$ & Design & Rockburst \\
\hline $\begin{array}{l}\text { To improve the stability of the main underground infrastructure } \\
\text { (e.g. crusher chamber, crib room, workshop, vent raises, accesses, } \\
\text { and conveyor decline), the location shall be determined based on } \\
\text { geological structures, in situ and induced stress condition, and } \\
\text { strength of the rock mass, and dynamic ground support shall be } \\
\text { installed }\end{array}$ & Design & Rockburst \\
\hline $\begin{array}{l}\text { Cave monitoring systems shall be installed prior to cave } \\
\text { establishment activities and shall cover the entire footprint, accesses } \\
\text { and main underground infrastructure (e.g. crusher chamber, crib } \\
\text { room, workshop, vent raises, accesses, and conveyor decline) }\end{array}$ & Design & Caving hazards \\
\hline $\begin{array}{l}\text { Dynamic ground support shall be already installed before abutment } \\
\text { stresses are induced ahead of the cave front }\end{array}$ & Design & Rockburst \\
\hline $\begin{array}{l}\text { Ground support system capacities shall be maintained throughout } \\
\text { the life of the asset to ensure design performance is realised in the } \\
\text { event of loading }\end{array}$ & Design & Rockburst \\
\hline $\begin{array}{l}\text { Ground support designs and maintenance programs shall consider } \\
\text { all loading mechanisms, the design life and the current and future } \\
\text { environmental conditions }\end{array}$ & Design & Rockburst \\
\hline
\end{tabular}




\subsection{Cave initiation rules}

The cave initiation rules apply to the undercut and drawbell fronts management activities. It also includes the location from where the undercutting process will commence and the minimum number and arrangement of drawbells that are required to initiate the caving propagation process.

The cave initiation rules are summarised in Table 9.

\section{Table 9 Cave initiation rules}

\begin{tabular}{|c|c|c|}
\hline Cave initiation rules & Design/operation & Risk to mitigate \\
\hline $\begin{array}{l}\text { The preferred undercutting methodology shall be } \\
\text { post-undercutting, in combination with intensive } \\
\text { preconditioning and a high undercut to manage stresses, } \\
\text { reduce development and improve fragmentation }\end{array}$ & Design & $\begin{array}{l}\text { Rockburst, } \\
\text { collapses, } \\
\text { oversize rocks }\end{array}$ \\
\hline $\begin{array}{l}\text { Cave initiation shall start from existing caves and retreat } \\
\text { away to facilitate cave initiation, reduce stress } \\
\text { concentrations and potential rockburst risk }\end{array}$ & Operation & $\begin{array}{l}\text { Rockburst, } \\
\text { collapses }\end{array}$ \\
\hline $\begin{array}{l}\text { Undercutting front orientation shall not be parallel to the } \\
\text { seismically dominant geological feature, nor to the in situ } \\
\text { principal stress direction, to reduce potential rockburst risk } \\
\text { and collapses }\end{array}$ & Operation & Rockburst \\
\hline $\begin{array}{l}\text { Undercutting front shall be less than } 350 \mathrm{~m} \text { to reduce } \\
\text { stress concentrations over time }\end{array}$ & Design & $\begin{array}{l}\text { Rockburst, } \\
\text { collapses }\end{array}$ \\
\hline $\begin{array}{l}\text { Extraction angle shall be in the range of } 30 \text { to } 45^{\circ} \text { to reduce } \\
\text { riling material and promote even cave propagation }\end{array}$ & Operation & $\begin{array}{l}\text { Early dilution } \\
\text { and reserves } \\
\text { losses }\end{array}$ \\
\hline $\begin{array}{l}\text { Lead lag shall be only one drawbell opened ahead of the } \\
\text { cave front to reduce stress concentrations and potential } \\
\text { rockburst }\end{array}$ & Operation & Rockburst \\
\hline $\begin{array}{l}\text { Undercut rate shall be determined based on both the new } \\
\text { area required to maintain the production rate and the } \\
\text { seismic response of the rock mass }\end{array}$ & Design/operation & Rockburst \\
\hline
\end{tabular}




\subsection{Cave propagation rules}

Cave propagation corresponds to the upward cave growth due to mucking activities. This stage follows the cave initiation. In this stage, enough drawbells have been commissioned to ensure the full mobilisation of the ore column above the constructed drawbells. Cave propagation rules are summarised in Table 10.

Table 10 Cave propagations rules

\begin{tabular}{lll}
\hline Cave propagation rules & Design/operation & Risk to mitigate \\
\hline $\begin{array}{l}\text { Even draw shall be established as the draw strategy to } \\
\text { prevent isolated growth zones and to avoid early dilution }\end{array}$ & Operation & Early dilution \\
$\begin{array}{l}\text { Draw rate shall be less than cave propagation rate to } \\
\text { avoid excessive airgap and prevent airblast risk }\end{array}$ & Operation & Airblast \\
$\begin{array}{l}\text { Any drive currently or forecasted to intersect the cave } \\
\text { shall have an engineered airblast plug to reduce exposure } \\
\text { to personnel and mine infrastructure }\end{array}$ & Operation & Airblast \\
$\begin{array}{l}\text { Allocation of secondary breakage resources shall be } \\
\text { prioritised to manage oversize rocks at the drawpoints to } \\
\text { ensure even draw }\end{array}$ & Operation & Oversize \\
$\begin{array}{l}\text { Open drawpoints shall be bunded to avoid material riling } \\
\text { into the extraction drives when access by personnel is } \\
\text { required }\end{array}$ & Operation & $\begin{array}{l}\text { Uncontrolled } \\
\text { material } \\
\text { movement }\end{array}$ \\
\hline
\end{tabular}

\subsection{Cave breakthrough rules}

Cave breakthrough corresponds to the cave back intersecting a previously mined out area or reaching out to the surface. It also includes the cave interacting with an underground level, such as the cave engineering level (Table 11).

Table 11 Cave breakthrough rules

\begin{tabular}{lll}
\hline Cave breakthrough rules & Design/operation & Risk to mitigate \\
\hline $\begin{array}{l}\text { If any excavation which is linked to infrastructure such as } \\
\text { level access, decline, raises, etc. will be intersected by the } \\
\text { cave, an engineered plug shall be in place well before cave } \\
\text { breakthrough }\end{array}$ & Operation & Airblast \\
$\begin{array}{l}\text { Cave breakthrough shall be monitored from surface followed } \\
\text { by ongoing monitoring of the crater and subsidence zone to } \\
\text { determine any unexpected impact on surface infrastructure }\end{array}$ & Design & Subsidence \\
$\begin{array}{l}\text { Critical crown pillar thickness shall be determined before } \\
\text { undercutting commences to ensure a surface exclusion zone } \\
\text { can be implemented well in advance. This also applies to } \\
\text { development areas above the cave footprint }\end{array}$ & Design/operation & $\begin{array}{l}\text { Subsidence and } \\
\text { flying rocks }\end{array}$ \\
\hline
\end{tabular}




\section{Conclusion}

A strong safety culture, combined with innovative thinking, has allowed Cadia to challenge existing industry paradigms using empirical data, a proof of concept type approach, followed by rapid implementation. These challenges have been the result of deep mining in hard rock, in a high-stress environment, as well as choosing to mine the orebody with a single lift in order to maximise the business returns.

The key learnings to date are as follows:

- Fragmentation is a key parameter that changes over time, and this change in an operating environment is significant for a cave with a very high ore column.

- Mine design and infrastructure make a significant difference to the ramp-up experience with larger loaders and an El Teniente layout contributing to significant uplift in performance.

- Preconditioning through hydraulic fracturing has proven to provide a step change in the safety and business outcomes for high-stress deep caves at minimal cost.

- Post-undercut methodology, in conjunction with high undercut $(20 \mathrm{~m})$ and intensive preconditioning has proven to provide the best production ramp-up across Cadia's caving operations and should be embraced where it is safe to execute.

\section{Acknowledgement}

The authors acknowledge the support of Newcrest Mining and Cadia Valley Operations for allowing the publication of this paper, and the staff that supplied data, information and insights into this work.

\section{References}

Brunton, I, Lett J \& Thornhill, T 2016, 'Fragmentation prediction and assessment at the Ridgeway Deeps and Cadia East cave operations', Proceedings of MassMin 2016, The Australasian Institute of Mining and Metallurgy, Melbourne.

Flores, G 2014, 'Future challenges and why cave mining must change', in R Castro (ed.), Proceedings of the Third International Symposium on Block and Sublevel Caving, Universidad de Chile, Santiago, pp. 23-52.

Landeros, P, Cuello, D \& Rojas, E 2012, 'Caveback Management at Reservas Norte Mine, Codelco Chile El Teniente Division', Proceedings of MassMin 2012, Canadian Institute of Mining, Metallurgy and Petroleum, Westmount.

Pardo, C \& Rojas, E 2016, 'Selection of exploitation method based on the experience of hydraulic fracture techniques at El Teniente Mine', Proceedings of MassMin 2016, The Australasian Institute of Mining and Metallurgy, Melbourne. 
Key geotechnical knowledge and practical mine planning guidelines in deep, high-stress, hard rock conditions for block and panel cave mining 